\title{
Effect of teleconnection patterns on ice conditions in lakes in lowland Poland
}

\author{
Mariusz Ptak ${ }^{1}$ - Arkadiusz M. Tomczyk ${ }^{2}$ (1) Dariusz Wrzesiński ${ }^{1}$ Ewa Bednorz ${ }^{2}$
}

Received: 25 April 2019 / Accepted: 18 June 2019 / Published online: 18 July 2019

(C) The Author(s) 2019

\begin{abstract}
Ice conditions in lakes are one of the basic factors considerably affecting the functioning of lake ecosystems, and the term of ice end modifies the course of further processes (thermal stratification, biological conditions, etc.) occurring outside the winter season. The paper presents the analysis of the effect of teleconnection patterns (NAO, SCAND, EA, EAWR) on ice conditions in lakes in North Poland, determining the relations between the teleconnection conditions in the cold half-year and selected features of the ice regime, i.e. dates of ice start and ice end, ice duration, and maximum ice thickness. Deviations of values of the aforementioned parameters in positive and negative phases of the considered teleconnection patterns were calculated in reference to mean values from the years 1956-2014. Two of them were determined to have considerable effect on the parameters of the ice regime, namely NAO, modifying ice start and ice end, ice duration, and maximum ice thickness in the season, and SCAND, considerably changing ice end, ice duration, and maximum ice thickness. The EA teleconnection pattern only affects ice end, and EAWR shows no correlations with the analysed ice parameters in lakes.
\end{abstract}

\section{Introduction}

One of the basic features of lakes at moderate latitudes is the development of ice cover. Its occurrence evidently differentiates the functioning of the ecosystems into two separate seasons in the annual scale. Due to the isolation of water from energy and matter exchange with the surroundings, certain processes completely disappear, and others are of a character other than in periods free from ice. Bonsal et al. (2006) emphasise that ice duration and composition control the seasonal thermal budget of lakes, determining the evaporation volume, stratification duration and productivity of the ecosystems. In the context of global warming, the current patterns of

Electronic supplementary material The online version of this article (https://doi.org/10.1007/s00704-019-02929-2) contains supplementary material, which is available to authorized users.

\section{Arkadiusz M. Tomczyk}

atomczyk@amu.edu.pl

1 Department of Hydrology and Water Management, Institute of Physical Geography and Environmental Planning, Adam Mickiewicz University, Poznań, Poland

2 Department of Climatology, Institute of Physical Geography and Environmental Planning, Adam Mickiewicz University, B. Krygowskiego 10, 61-680 Poznań, Poland parameters of the ice regime are subject to evident transformations, and numerous studies in the scope suggest a general reduction of the ice season duration (Cai et al. 2017; Magee and Wu 2017; Nowak et al. 2018). Due to the shift of ice end, the term of development of thermal-density water stratification occurs earlier, and as a consequence the epilimnion layer heats up faster and longer (Ptak et al. 2018a). In a broader spatial approach, faster ice end on lakes (temperate and polar zone) contributes to their faster heating in comparison with lakes in which the freezing process does not normally occur (Kintisch 2015). As emphasised by Schmidt et al. (2019), next to long-term warming, teleconnection patterns are recognised to cause anomalies in the range of temperatures on the Northern Hemisphere in a temporal scale from weeks to decades. In the case of Central Europe, the teleconnection pattern associated with the North Atlantic Oscillation (NAO) is of key importance for climatic conditions. In reference to processes occurring in lakes, the effect of NAO in this part of Europe is relatively thoroughly investigated, and refers to among others water stages (Wrzesiński et al. 2018), water temperature (Wrzesiński et al. 2015a), or ice conditions (Bernhardt et al. 2012).

In a broader approach considering the effect of other teleconnection patterns on the functioning of lake ecosystems in this region of Europe, however, more detailed research is still required, as emphasised by among others Ptak et al. 
(2018b). The authors analysed the effect of several teleconnection patterns (including NAO, the Scandinavian pattern (SCAND), East-Atlantic pattern (EA), East-European pattern (EAWR)) on the temperature of surface waters, determining correlations between particular variables. The research presented in the paper is a continuation of the issue in reference to ice conditions in lakes, supplementing knowledge concerning one of the most important characteristics shaping the course of the entirety of processes and phenomena occurring in lakes - both in the winter season and outside it.

The objective of the paper was the determination of the temporal and spatial effect of teleconnection patterns (NAO, SCAND, EA, EAWR) on changes in ice conditions in Central Europe, based on Polish lakes. It was implemented through the determination of correlations of teleconnection indices with selected parameters of ice conditions in lakes, and determination of their deviations from mean values in different phases of the analysed teleconnection patterns.

\section{Data and methods}

The study employed two data sets. The first one included dates of ice start and ice end, ice duration and maximum ice thickness in particular years in the period 1956-2014. The aforementioned data were obtained from the resources of the Institute of Meteorology and Water Management, National Research Institute, for 14 lakes located in the lakeland zone of North Poland (Fig. 1). The area is characterised by a high number of lakes (95\% of all lakes in Poland) the genesis of which is related to the presence of the last Scandinavian glaciation. The basic morphometric parameters of the analysed lakes are presented in Table 1.

The second data set included monthly index values of teleconnection patterns, namely NAO, SCAND, EA and EAWR, obtained from data bases of the Climate Prediction Centre (CPC) NOAA (1956-2014). The aforementioned patterns were designated by means of the principal component analysis based on monthly values of anomalies of height of isobaric surface of $500 \mathrm{hPa}$ (Barnston and Livezey 1987). The first stage of work involved the calculation of the Spearman rank correlation coefficient between ice start and ice end, ice duration, maximum ice thickness and the index value of each teleconnection pattern. For dates of ice start, averaged index values from months from November to January were considered (NDJ), and for dates of ice end, ice duration and maximum ice thickness from months from December to March (DJFM). For the purpose of estimation of the value of total impact of all teleconnection patterns on ice conditions in lakes, multiple regression was calculated for each parameter characterising the ice conditions (R). Monthly parameters of ice conditions in lakes were adopted as the independent variable, and indices of four teleconnection patterns as dependent variables, in the same configuration as in the case of calculation of the Spearman rank correlation coefficient. The interpretation employed the determination coefficient $\left(R^{2}\right)$, permitting the determination of the percent of variance of ice conditions accounted for by the variability of the four considered teleconnection patterns.

Changes of the dates of ice start and ice end, ice duration and maximum ice thickness in different phases of the analysed teleconnection patterns were determined based on differences in the parameters in the positive and negative phase in

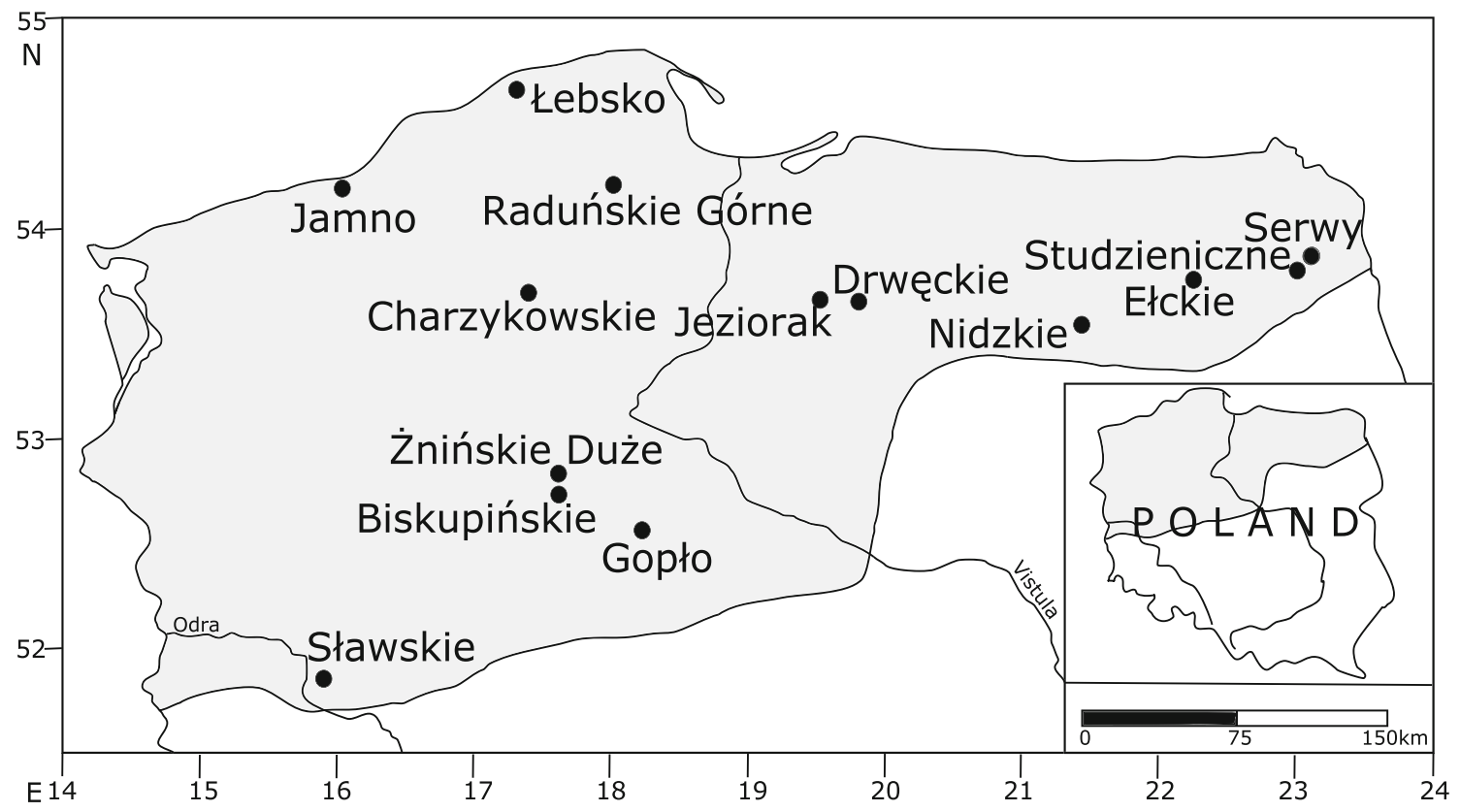

Fig. 1 Location of study lakes, grey colour - extent of glaciation during the last ice age within Poland 
Table 1 Parameters of the analysed lakes (after, Choiński 2006)

\begin{tabular}{|c|c|c|c|c|c|c|c|}
\hline No. & Lake & $\begin{array}{l}\text { Latitude } \\
\mathrm{N}\end{array}$ & $\begin{array}{l}\text { Longitude } \\
\text { E }\end{array}$ & $\begin{array}{l}\text { Depth max } \\
\text { (m) }\end{array}$ & $\begin{array}{l}\text { Depth mean } \\
\text { (m) }\end{array}$ & $\begin{array}{l}\text { Area } \\
\text { (ha) }\end{array}$ & $\begin{array}{l}\text { Volume (tys. } \\
\mathrm{m}^{3} \text { ) }\end{array}$ \\
\hline 1 & Sławskie & 51.89 & 16.02 & 12.3 & 5.2 & 822.5 & $42,664.8$ \\
\hline 2 & Gopło & 52.61 & 18.35 & 16.6 & 3.6 & 2121.5 & $78,497.0$ \\
\hline 3 & Biskupińskie & 52.79 & 17.74 & 13.7 & 5.5 & 107.0 & 6397.0 \\
\hline 4 & Żnińskie Duże & 52.86 & 17.73 & 11.1 & 6.8 & 420.5 & $29,492.6$ \\
\hline 5 & Charzykowskie & 53.77 & 17.50 & 30.5 & 9.8 & 1336 & $134,533.2$ \\
\hline 6 & $\begin{array}{l}\text { Raduńskie } \\
\text { Górne }\end{array}$ & 54.24 & 17.98 & 43.0 & 15.5 & 362.5 & $60,158.7$ \\
\hline 7 & Jamno & 54.27 & 16.15 & 3.9 & 1.4 & 7080.0 & 2231.5 \\
\hline 8 & Łebsko & 54.65 & 17.10 & 6.3 & 1.6 & 7020 & $117,521.0$ \\
\hline 9 & Jeziorak & 53.72 & 19.62 & 12.9 & 4.1 & 3.152 .5 & $141,594.2$ \\
\hline 10 & Drwęckie & 53.69 & 19.90 & 22.0 & 5.7 & 780.0 & $50,140.1$ \\
\hline 11 & Nidzkie & 53.57 & 21.54 & 23.7 & 6.2 & 1750.0 & $113,872.3$ \\
\hline 12 & Ełckie & 53.80 & 22.34 & 55.8 & 15.0 & 385.0 & $57,420.3$ \\
\hline 13 & Studzieniczne & 53.87 & 23.12 & 30.5 & 8.7 & 244 & $22,073.6$ \\
\hline 14 & Serwy & 53.90 & 23.20 & 41.5 & 14.1 & 438.5 & $67,181.5$ \\
\hline
\end{tabular}

reference to average values from the years 1956-2014. For this purpose, the analysed parameters were selected for 15 years with high and 15 years with low index values of the analysed teleconnection patterns. The numbers correspond with the first and third quartile from the entire set of indices in the years 1956-2014. The statistical significance of the differences was analysed by means of a $t$ test for dependent samples. Each time the hypothesis $\mathrm{H}_{0}: \mu=\mu_{0}$ with equality of expected values was tested against $H_{1}: \mu \neq \mu_{0}$. Rejection of the hypothesis suggests significant differences between the analysed parameters in different phases and their average values from the years 1956-2014. The verification of the hypothesis involved the application of a test for a small sample based on $t$ Student distribution, at $n$-1 degreed of freedom:

$t=\left|\frac{\bar{x}-\mu_{0}}{s} \sqrt{n}\right|$

where $n$ is sample size, $s$ is standard deviation, $\bar{x}$ is mean from sample and $\mu_{0}$ is mean from population.

\section{Results}

\subsection{Mean characteristics of ice conditions in lakes}

The general distribution of the conditions of ice duration and ice end in Poland shows meridional orientation. The situation is determined by the features of transitional climate, characteristic of this part of Europe. Features of continental climate in the east of Poland become obscured and transition into features of marine climate in the west. It is manifested among others in more frosty and longer winters (Woś 2010), translating into the term of ice end, ice duration and maximum ice thickness (Fig. 2). This pattern overlaps with individual parameters of lakes, as particularly evidently observed at the moment of development of ice cover (Choiński et al. 2015).

\subsection{Effect of teleconnection patterns on ice conditions in lakes}

Ice start was significantly statistically correlated with NAO. The calculated correlation coefficient $R$ was positive. The strongest correlation with a value of 0.5 was recorded in the case of Lake Charzykowskie, where the aforementioned teleconnection pattern accounted for approximately $25 \%$ of the variance of the date of ice start. In the negative phase of NAO, ice start occurred earlier by an average of 8 days. The highest deviations from the mean value were determined on Lake Charzykowskie (14 days) and Lake Ełckie (12 days) (Fig. 3). In the positive phase of NAO, ice start was recorded later by an average of 9 days. Like in the case of the negative phase, the highest deviation was determined in Lake Charzykowskie (13 days). Moreover, a delay of more than 10 days was observed in Lakes Sławskie and Łebsko (11 days). Both in the positive and negative phases, the recorded differences were statistically significant over an inconsiderable area. In spite of the determined weak effect of NAO on ice start in the winter season, and even weaker effect of the remaining teleconnection patterns, multiple regression was calculated expressing the total effect of all four teleconnection patterns considered in the study. Like in the case of the predominant teleconnection pattern (NAO), the strongest correlation of ice start with teleconnection pattern was determined in the case of Lake Charzykowskie, where the variability of ice start depends on the teleconnection conditions in 

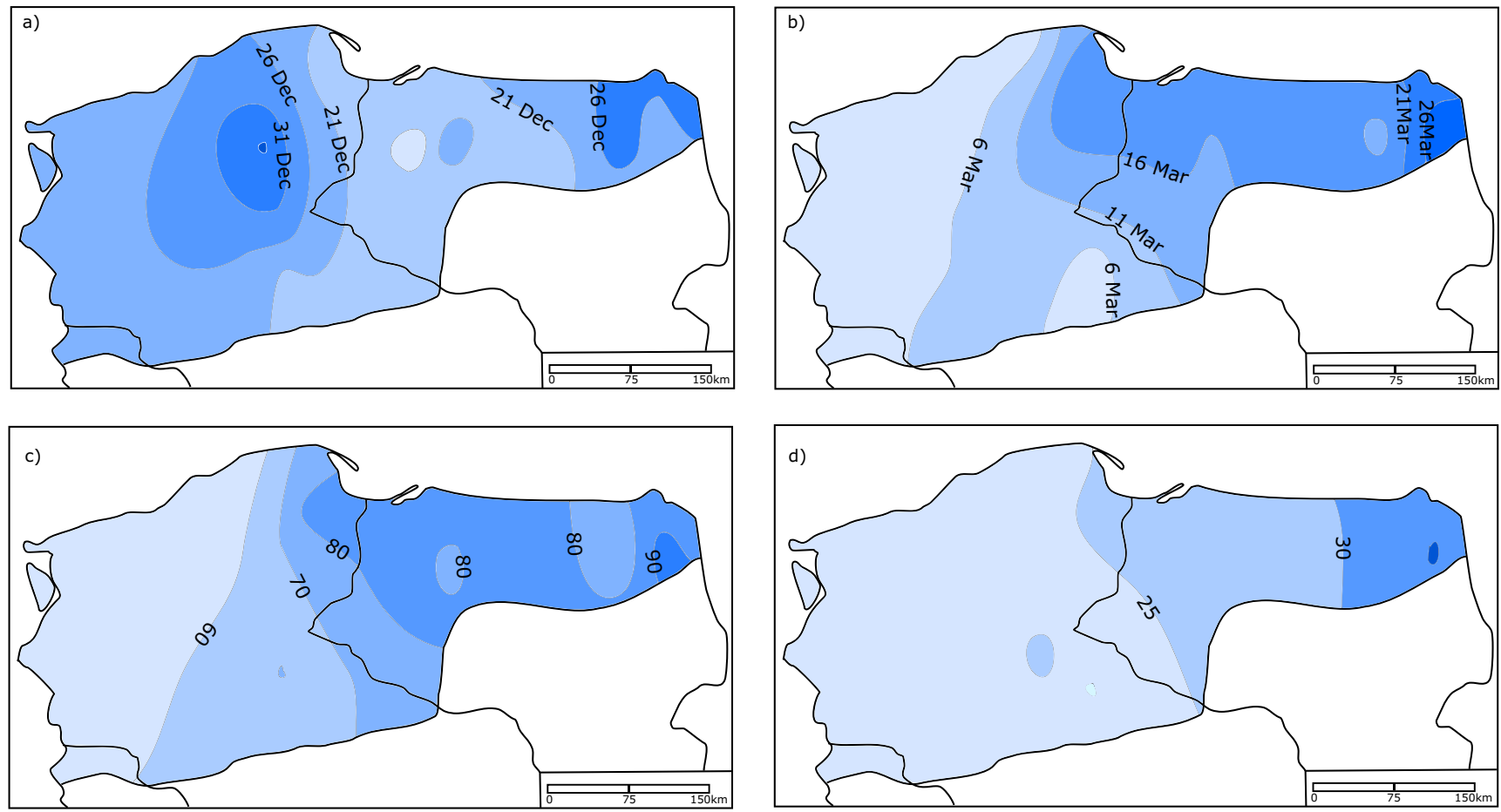

Fig. 2 Mean parameters of ice conditions in Polish lakes; $\mathbf{a}$ dates of ice start, $\mathbf{b}$ dates of ice end, $\mathbf{c}$ ice duration and $\mathbf{d}$ maximum ice thickness

approximately $37 \%\left(R^{2}=0.37\right)$. In the remaining lakes, the correlation of the first phase of ice conditions with teleconnection conditions is weak; the multiple regression $(R)$ varies from 0.27 (Jeziorak) to 0.46 (Sławskie) (Fig. 4).

\subsection{Ice end}

Ice end was significantly statistically correlated with three teleconnection patterns, namely with NAO, SCAND and EA, whereas the strongest correlations were determined for the first two patterns. The calculated coefficient of correlation between $\mathrm{NAO}$ and date of ice end in the analysed lakes was negative and significant at a level of $p<0.001$. The strongest correlations $(R$ $<-0.6)$ were recorded in the case of lakes located in the northern and eastern regions of the study area. The strongest effect of NAO on ice end occurred in Lake Studzieniczne and Nidzickie, where the said teleconnection pattern explained more than $45 \%$ of the variance of ice end. In the negative phase of NAO, ice end was delayed by an average of 17 days. The delay varied from 13 days in Lake Studzieniczne, Serwy and Żnińskie to 23 days in Lake Łebsko. In the positive phase of NAO, ice end was observed earlier, like in the negative phase, by an average of 17 days. The acceleration of ice end varied from 9 days in Lake Charzykowskie to 22 days in Lake Ełckie. In the case of both phases, the differences were statistically significant. As mentioned earlier, ice end was also statistically correlated with SCAND the pattern, and the calculated correlation coefficient $R$ was positive. Except for the lakes located in the central regions of the study area, the correlation coefficient was $R>0.3$. This teleconnection pattern accounted for a maximum of $>15 \%$ of the variance of data of ice end in Lake Nidzickie. In the negative phase of SCAND, ice end was observed earlier by an average of 16 days. The lowest deviation from the average date was recorded in Lake Charzykowskie ( 9 days), and the highest in Lake Ełckie (21 days), as well as in Lakes Drwęckie and Nidzickie (20 days). In the positive phase of SCAND, ice end was observed later by an average of 11 days. On particular lakes, the delay varied from 6 days in Lake Charzykowskie to 13 days in Lakes Drwęckie, Ełckie, Jeziorak and Łebsko. In the case of the majority of lakes, the differences were statistically significant. The coefficient of correlation between the EA index and date of ice end suggests a weak effect of the pattern on the analysed parameter. The calculated coefficient was negative, and in the majority of lakes statistically significant. Except for Lake Gopło (12\%), it explained less than $10 \%$ of the variance of ice end date. In the case of the EAWR pattern, no statistically significant effect on ice end in the lakes of North Poland was determined. The total effect of four winter teleconnection patterns on ice end is the greatest in the eastern part of the study area, where the variability of intensity of teleconnection patterns accounts for more than $50 \%$ of the variability of the term of occurrence of the last ice in the season $\left(R^{2}>0.57\right.$ for Lakes Nidzkie and Studzieniczne). The correlation of winter

Fig. 3 Spatial distribution of coefficients of correlation and deviations in parameters of ice conditions from mean values in different phases of teleconnection patterns; $\mathbf{a}$ dates of ice start, $\mathbf{b}$ dates of ice end, $\mathbf{c}$ ice duration and $\mathbf{d}$ maximum ice thickness; $p$ level of significance 

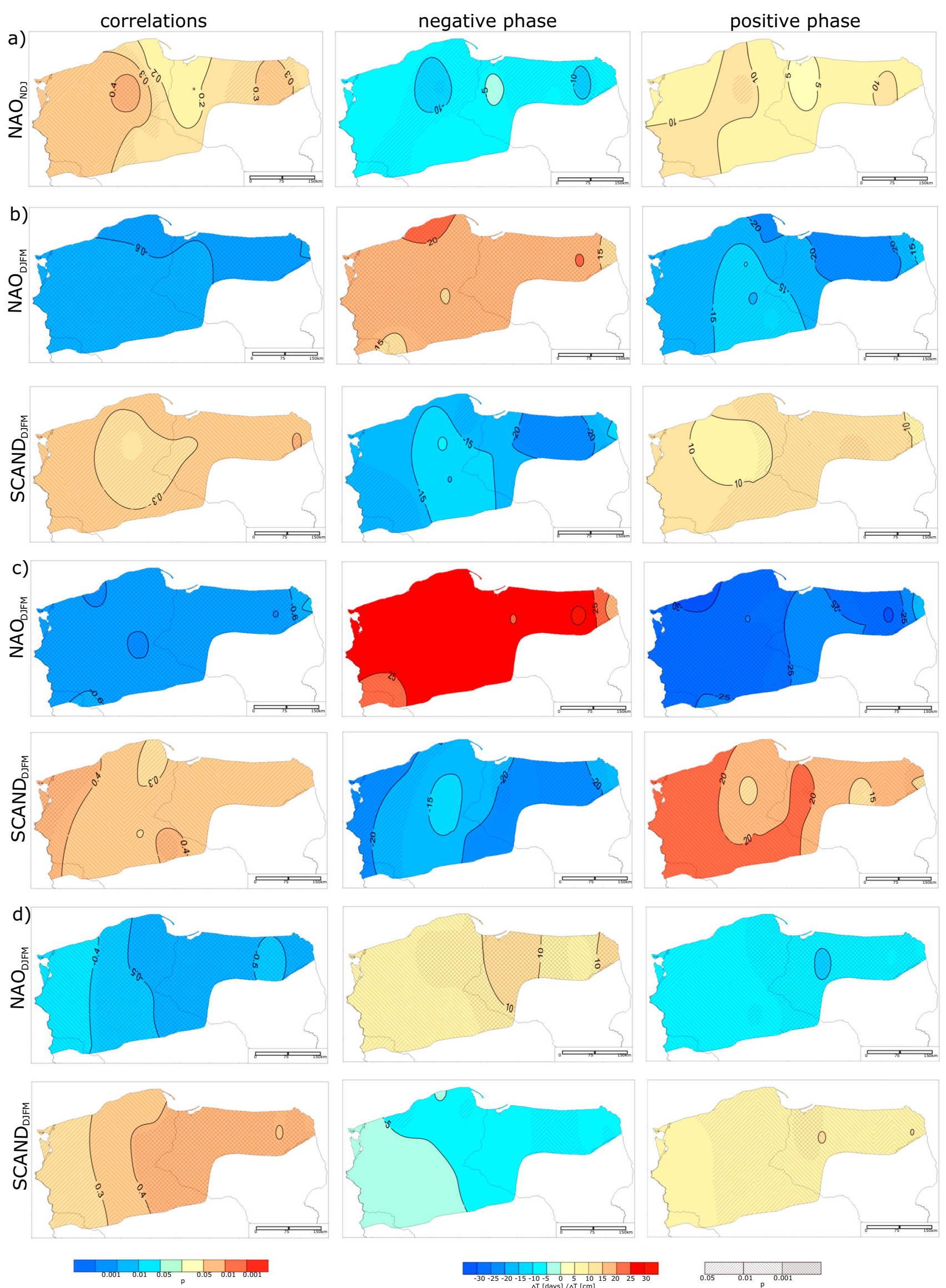
teleconnection indices with prolonged ice duration is weaker in the western part, and $R^{2}$ decreases to 0.34 for Lakes Ostrzyckie and Charzykowskie.

\subsection{Ice duration}

Ice duration was significantly correlated with two teleconnection patterns, namely with NAO and SCAND. In the case of the former pattern, the correlation coefficient was negative, and throughout the area significant at a level of $p<0.001$. In the analysed years, NAO explained from $23 \%$ in Lake Serwy to $52 \%$ of the variance of ice duration in Lake Żnińskie. In the negative phase of NAO, the recorded ice duration was longer by an average of 26 days. In the analysed lakes, the prolongation of ice duration was variable, and varied from 19 days in Lake Serwy to 31 days in Lake Ełckie. In the positive phase of NAO, ice duration was shorter by an average of 26 days. Deviations from the mean value varied from 17 days in Lake Serwy to 31 days in Lake Ełckie. Moreover, a reduction of ice duration of more than 30 days was observed in Lake Jamno. In both phases, the differences were statistically significant $(p<0.05)$. The SCAND pattern had weaker effect on ice duration, and explained a maximum of up to $20 \%$ of the variance of ice duration in Lake Jamno. The calculated correlation coefficient $R$ was positive. The negative phase of SCAND was related to a reduction of ice
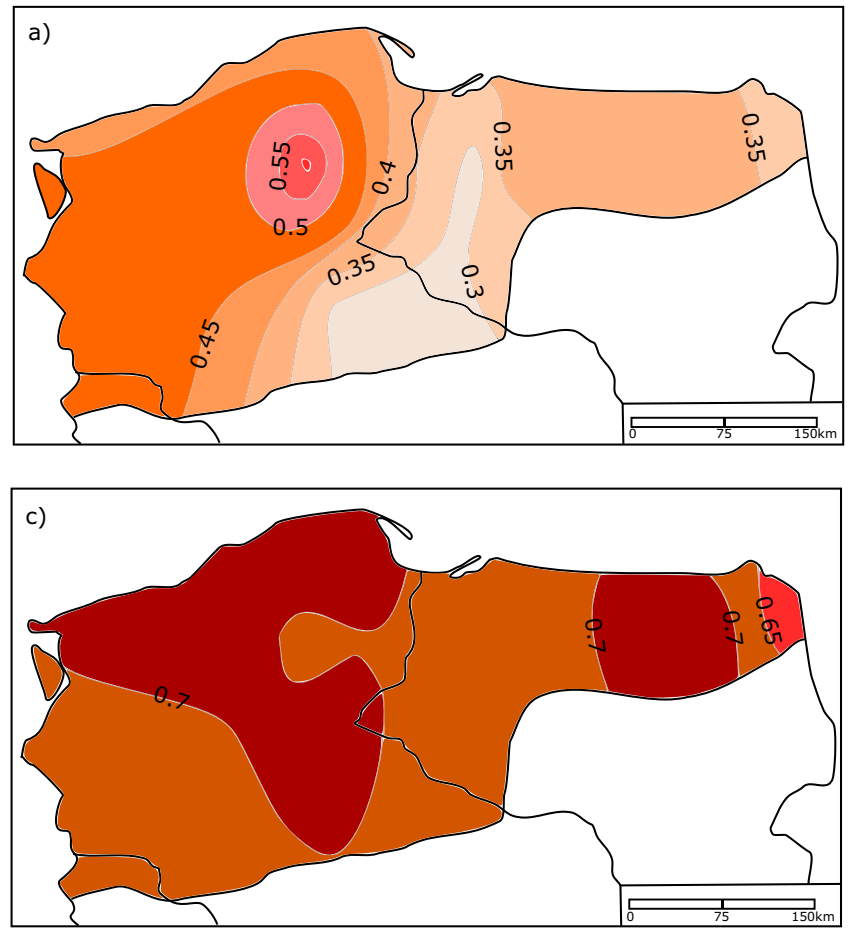

duration by an average of 18 days. The smallest changes in ice duration in the phase were recorded in Lake Żnińskie and Charzykowskie - approximately 13 days, and the greatest in Lake Nidzickie - as many as 22 days, as well as in Lakes Drwęckie, Ełckie, Gopło, Jamno, Jeziorak and Łebsko (> 20 days). In the positive phase, ice duration was longer by an average of 18 days. The prolongation of ice duration varied from 13 days in Lakes Charzykowskie and Nidzickie to 24 days in Lake Jamno. An equal prolongation of ice duration ( $>20$ days) was recorded in Lakes Ełckie, Jeziorak, Gopło and Stawskie. In the case of the negative phase, the observed differences were statistically significant for lakes located in the western and eastern regions, and in the positive phase throughout the study area. Among all parameters of ice conditions, ice duration is a parameter most dependent on winter teleconnection conditions throughout the study area. The total effect of the four considered teleconnection patterns is substantial. They account for approximately $50 \%$ of the variability of ice duration in lakes in North Poland.

\subsection{Maximum ice thickness}

Maximum ice thickness, similarly as ice duration, was significantly correlated particularly with two teleconnection patterns, namely NAO and SCAND. The coefficient of correlation between NAO and maximum ice thickness was negative
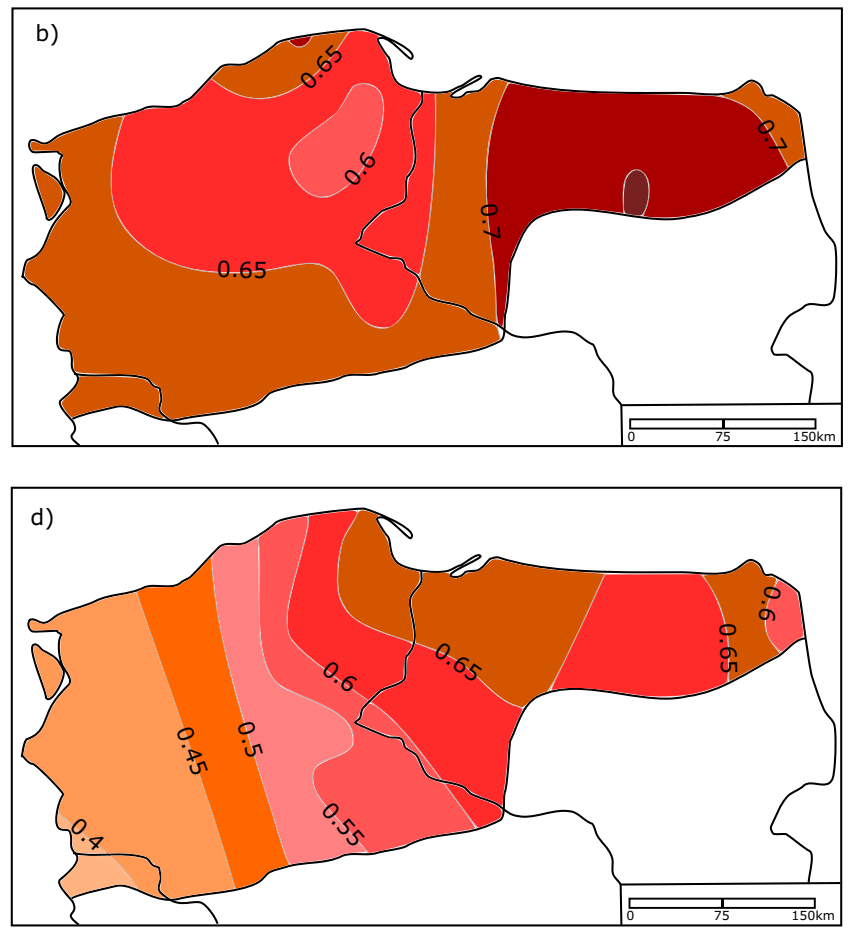

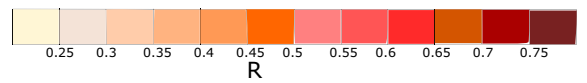

Fig. 4 Spatial distribution of the multiple regression coefficient; $\mathbf{a}$ dates of ice start, $\mathbf{b}$ dates of ice end, $\mathbf{c}$ ice duration and $\mathbf{d}$ maximum ice thickness 
and statistically significant at a level of $p<0.001$ (with the exception of lakes in the western regions of the country). The analysed teleconnection pattern explained the greatest part of the variance of maximum ice thickness in the case of lakes located east of the Vistula River, with a maximum in Lake Studzieniczne (approximately 33\%). In the negative phase of NAO, the recorded maximum ice thickness values were higher by approximately $9 \mathrm{~cm}$. In particular lakes, the values varied from $6 \mathrm{~cm}$ in Lake Slawskie to $13 \mathrm{~cm}$ in Lake Drwęckie and Studzieniczne. In the positive phase, the recorded maximum ice thickness values were lower by an average of $8 \mathrm{~cm}$. Deviations from the mean value varied from $6 \mathrm{~cm}$ in Lake Sławskie to $11 \mathrm{~cm}$ in Lake Drwęckie. In both phases, the differences were statistically significant $(p<0.05)$. As mentioned earlier, maximum ice thickness was also statistically significantly correlated with the SCAND pattern. The correlation coefficient was positive, and reached the highest values $(R>0.4)$ in the east of the study area, where it accounted for a maximum of $24 \%$ of the variance of maximum ice thickness. In the negative phase of SCAND, the recorded maximum ice thickness values were lower by an average of $6 \mathrm{~cm}$, and in the positive phase higher by an average of $7 \mathrm{~cm}$. Both in the negative and positive phase, no considerable spatial variability of deviations from the mean value was determined. In the negative phase, the differences were statistically significant particularly in lakes in the eastern regions of the study area, and in the positive phase outside the western regions. Moreover, a statistically significant correlation was determined in several lakes between EA and maximum ice thickness. Except for Lake Serwy (11\%), however, the pattern did not account for more than $8 \%$ of the variance of maximum ice thickness. In the case of the EAWR pattern, no statistically significant correlations with maximum ice thickness were determined. Total effect of the four winter teleconnection patterns on the maximum ice thickness recorded in the season in the lakes of North Poland is spatially variable, and evidently increases from the west to the east. In the western part of the study area, the variability of phases and intensity of teleconnection patterns explains the variability of maximum ice thickness from season to season the weakest, in only approximately $16-20 \%$, and in the western part of the study area the effect of winter teleconnection on ice thickness exceeds $50 \%$.

\section{Discussion}

The analysed teleconnection patterns showed variable effect on the course of ice conditions in Polish lakes. NAO and SCAND played the greatest role in shaping the ice regime, followed by EA, and the EAWR pattern showed no significant correlations. The total effect of all teleconnection patterns expressed in percent variance of ice conditions showed the highest significance for ice duration, and lowest for ice start. The obtained results confirm observations to date concerning the predominant role of NAO in the analysed region on the ice conditions of surface waters (Girjatowicz 2003; Borowiak and Barańczuk 2004; Wrzesiński et al. 2013, 2015b). At a larger scale, the observed situation corresponds with research on the ice regime of European lakes and its relations to the NAO pattern (George 2007; Sanchez-Lopez et al. 2015). The research also shows that the development and course of the parameters of ice conditions in lakes is also determined by other teleconnection patterns. Analyses concerning the effect of several teleconnection patterns on ice conditions in lakes are a subject of numerous studies (Bonsal et al. 2006; Bai et al. 2012; Schmidt et al. 2019), showing the complexity of the relations depending on the analysed region. In the case of Central Europe, works concerning more than one teleconnection pattern were undertaken by among others Karetnikov and Naumenko (2011) or Soja et al. (2014) in reference to lakes located both north and south of the study area. In the former case, the analysis of ice conditions in Lake Ladoga (largest lake in Europe) showed that the AO index in winter months and local conditions (maximum accumulated freezing degree days) accounted for a major part of interannual changes in ice conditions. In the latter case, the analysis concerned Lakes Balaton and Neusiedl. The Mediterranean Oscillation and North Atlantic Oscillation show significant correlations with ice phenology in both lakes, whereas the East Atlantic teleconnection pattern is only related to the ice characteristics of Lake Neusiedl. Air temperature is of key importance for ice duration and ice end (Ptak et al. 2017). In reference to the main teleconnection pattern (NAO) shaping the course of ice conditions in lakes, according to Yoo and D'Odorico (2002), the pattern seems to particularly affect temperature in the late-winter period, with a considerable effect also in mid-spring, when air temperature is strongly correlated with ice dates. In reference to the earlier study concerning the effect of particular teleconnection patterns on air temperature (Ptak et al. 2018b), correlations between them can be analysed. In the positive phase of NAO, evidently higher than average air temperature was recorded. The highest deviations of air temperature from the multi-annual mean value were observed in February, exceeding $3{ }^{\circ} \mathrm{C}$ in the east. In the negative phase, evidently lower than average air temperature was recorded. Differences in air temperature increased from the west to the east. The highest deviations of air temperature from the multi-annual mean were determined in February. Like before, they exceeded $3{ }^{\circ} \mathrm{C}$ in the east. In the case of the SCAND pattern, in the positive phase lower than average air temperature was recorded. The highest deviations from the multi-annual mean occurred from January to March, and reached even $2.2^{\circ} \mathrm{C}$. In the negative phase of SCAND, higher than average air temperature was recorded. Deviations of air temperature increased from the west to the east (more 
than $3.5^{\circ} \mathrm{C}$ ). The EA pattern showed lower effect on air temperature than the other two patterns. In the positive phase of EA, higher than average air temperature was recorded. In April, deviations of air temperature from the mean value did not exceed $1{ }^{\circ} \mathrm{C}$. In the negative phase of EA, lower than average air temperature was recorded. In April, differences in temperature outside the north-western part of the study area exceeded $1^{\circ} \mathrm{C}$.

The spatial distribution of dependencies of air temperature on teleconnection patterns generally corresponds with the pattern of isolines concerning parameters of ice conditions, and it is primarily modified by individual features of particular lakes. In the case of development of ice cover, the depth of the lake is the most important (Korhonen 2006). Ice start (in accordance with mean terms) is the latest in the case of Lake Charzykowskie. The situation is determined by its location (in the zone with predominant warmer marine climate) and considerable depth allowing for the accumulation of greater amounts of heat. Due to this, heat is released longer, slowing down the development of ice cover. The aforementioned co-occurring conditions are modified the strongest by the total effect of all four teleconnection patterns, as expressed by multiple regression results (Fig. 4). The remaining parameters of ice conditions depend more on external (atmospheric) factors than processes occurring in the lake (Wrzesiński et al. 2015b).

The seasonality of the effect of teleconnection patterns should be considered in research referring to long-term changes in ice conditions in lakes. For example, in reference to NAO $_{\text {DJFM }}$ in the years 1962-1965, low indices of the pattern were recorded (frosty winters), and in the multi-annual period 1992-1995, the situation was the opposite (mild winters). The occurrence of particular teleconnection phases can therefore be an important factor affecting the direction and value of the trend of the course of particular parameters of ice conditions, simultaneously making the interpretation in a long-term approach more difficult. Moreover, particular indices can show variability from season to season, affecting the dynamics of the course of ice conditions even stronger. In reference to the aforementioned pattern $\left(\mathrm{NAO}_{\mathrm{DJFM}}\right)$, such a situation occurred among others in 1984 and 1985, where respectively high and low value of the index was recorded. This contributed to the respective reduction and increase in ice duration or ice thickness. In 1984, ice duration (average for all lakes) was longer by 7 days, and the maximum ice thickness was higher by $14 \mathrm{~cm}$ in comparison to the state from the subsequent year.

The term of ice end has consequences for the functioning of lake ecosystems in subsequent months. It is reflected in among others the course of physico-chemical parameters (as mentioned in the introduction in reference to changes in thermal-density conditions of water) or biological conditions. According to Yang et al. (2019), earlier ice end leads to earlier commencement of the stratification process, resulting in periods of advanced phytoplankton growth in the subsequent summer period. In the case of Lake Jasne (West Poland), Pełechata et al. (2015) determined that after mild winters, in spite of higher availability of nutrients in water, phytoplankton was less abundant than after severe winters, as reflected in the total abundance and biomass of chryzofioceae. Gerten and Adrian (2000) determined evident changes in the dynamics of phytoplankton in polymictic Lake Müggelsee (Germany) over the last two decades in the spring period. The authors evidenced that the changes were related to the effect of NAO. In the warm period, phytoplankton developed approximately 1 month earlier than in the cold period, and the aforementioned teleconnection pattern accounted for approximately $35 \%$ of the variance, and should be associated with a reduction or lack of ice cover in winter.

\section{Conclusions}

Out of the four teleconnection patterns analysed in the paper, significant correlations with parameters of ice conditions were particularly determined for two of them, namely NAO (ice start and end, ice duration, maximum ice thickness) and SCAND (ice end, ice duration, maximum ice thickness). Moreover, in the case of the EA pattern, its effect was determined to significantly determine the term of ice end, and in reference to the EAWR pattern no correlations with the analysed parameters of ice conditions were found. In reference to the NAO pattern, earlier research in the scope (conducted in shorter periods) was confirmed, showing significant correlations with all parameters of the ice regime. It should also be emphasised that the analysis of the effect of the remaining teleconnection patterns on ice conditions in lakes in this part of Europe is a new approach, and the obtained results provide the basis for undertaking more detailed research in the future (referring to e.g. biological conditions or water quality). Complex consideration of all components affecting the functioning of lake ecosystems is necessary in the context of the observed climatic changes, and the necessity of undertaking measures potentially mitigating the effects of the process.

Funding information This research was partly supported by the National Science Centre, Poland, grant number 2016/21/B/ST10/01440.

Open Access This article is distributed under the terms of the Creative Commons Attribution 4.0 International License (http:// creativecommons.org/licenses/by/4.0/), which permits unrestricted use, distribution, and reproduction in any medium, provided you give appropriate credit to the original author(s) and the source, provide a link to the Creative Commons license, and indicate if changes were made. 


\section{References}

Bai X, Wang J, Sellinger C, Clites A, Assel R (2012) Interannual variability of Great Lakes ice cover and its relationship to NAO and ENSO. JGR Oceans 117(3):C03002

Barnston AG, Livezey RE (1987) Classification, seasonality and persistence of low frequency atmospheric circulation patterns. Mon Weather Rev 115:1083-1126

Bernhardt J, Engelhardt C, Kirillin G, Matschullat J (2012) Lake ice phenology in Berlin-Brandenburg from 1947-2007: observations and model hindcasts. Clim Chang 112(3-4):791-817

Bonsal BR, Prowse TD, Duguay CR, Lacroix MP (2006) Impacts of large-scale teleconnections on freshwater-ice break/freeze-up dates over Canada. J Hydrol 330(1-2):340-353

Borowiak D, Barańczuk J (2004) Secular fluctuations of ice phenomena in Upper Radunia Lake, Kashubian Lakeland. Limnol Review 4:1724

Cai Y, Ke C-Q, Duan Z (2017) Monitoring ice variations in Qinghai Lake from 1979 to 2016 using passive microwave remote sensing data. Sci Total Environ 607(608):120-131

Choiński A (2006) Katalog jezior Polski. Wyd Nauk UAM, Poznań

Choiński A, Ptak M, Skowron R, Strzelczak A (2015) Changes in ice phenology on Polish lakes from 1961-2010 related to location and morphometry. Limnologica 53:42-49

George DG (2007) The impact of the North Atlantic Oscillation on the development of ice on Lake Windermere. Clim Chang 81:455-468

Gerten D, Adrian R (2000) Climate-driven changes in spring plankton dynamics and the sensitivity of shallow polymictic lakes to the North Atlantic Oscillation. Limnol Oceanogr 45(5):1058-1066

Girjatowicz JP (2003) The influence of the North Atlantic Oscillation on ice conditions in coastal lakes of the southern Baltic Sea. Ann Limnol Int J Limnol 39(1):71-80

Karetnikov S, Naumenko M (2011) Lake Ladoga ice phenology: mean condition and extremes during the last 65 years. Hydrol Process 25: 2859-2867

Kintisch E (2015) Earth's lakes are warming faster than its air: first ever global survey reveals summer lake temperatures rising at an alarming rate. Science 350(6267): 1449

Korhonen J (2006) Long-term changes in lake ice cover in Finland. Hydrol Res 37(4-5):347-363

Magee MR, Wu CH (2017) Effects of changing climate on ice cover in three morphometrically different lakes. Hydrol Process 31(2):308323

Nowak B, Nowak D, Ptak M (2018) Variability and course of occurrence of ice cover on selected lakes of the Gnieźnieńskie Lakeland (Central Poland) in the period 1976-2015. 10th Conference on Interdisciplinary Problems in Environmental Protection and Engineering EKO-DOK 44:00126. https://doi.org/10.1051/ e3sconf/20184400126
Pełechata A, Pełechaty M, Pukacz A (2015) Winter temperature and shifts in phytoplankton assemblages in a small Chara-lake. Aquat Bot 124:10-18

Ptak M, Wrzesiński D, Choiński A (2017) Long-term changes in the hydrological regime of high mountain lake Morskie Oko (Tatra Mountains, Central Europe). J Hydrol Hydromech 65(2):146-153

Ptak M, Sojka M, Choiński A, Nowak B (2018a) Effect of environmental conditions and morphometric parameters on surface water temperature in Polish lakes. Water 10:580

Ptak M, Tomczyk AM, Wrzesiński D (2018b) Effect of teleconnection patterns on changes in water temperature in Polish lakes. Atmosphere 9(66):1-17

Sanchez-Lopez G, Hernández A, Pla-Rabes S, Toro M, Granados I, Sigró J, Trigo RM, Rubio-Inglés MJ, Camarero L, Valero-Garcés B, Giralt $\mathrm{S}$ (2015) The effects of the NAO on the ice phenology of Spanish alpine lakes. Clim Chang 130:101-113

Schmidt DF, Grise KM, Pace ML (2019) High-frequency climate oscillations drive ice-off variability for northern hemisphere lakes and rivers. Clim Chang 152:517-532. https://doi.org/10.1007/s10584018-2361-5

Soja AM, Kutics K, Maracek K, Molnár G, Soja G (2014) Changes in ice phenology characteristics of two central European steppe lakes from 1926 to 2012 - influences of local weather and large scale oscillation patterns. Clim Chang 126:119-133

Woś A (2010) Climate of Poland in the second half of 20th century. Wyd Nauk UAM, Poznań

Wrzesiński D, Ptak M, Baczyńska A (2013) Effect of the North Atlantic Oscillation on ice phenomena on selected lakes in Poland over the years 1961-2010. Quaest Geogr 32(3):119-128

Wrzesiński D, Choiński A, Ptak M (2015a) Effect of the North Atlantic Oscillation on the thermal characteristics of lakes in Poland. Acta Geophys 63(3):863-883

Wrzesiński D, Choiński A, Ptak M, Skowron R (2015b) Effect of the North Atlantic Oscillation on the pattern of lake ice phenology in Poland. Acta Geophys 63(6):1664-1684

Wrzesiński D, Ptak M, Plewa K (2018) Effect of the North Atlantic Oscillation on water level fluctuations in lakes of northern Poland. Geogr Pol 91(2):243-259

Yang Q, Song K, Wen Z, Hao X, Fang C (2019) Recent trends of ice phenology for eight large lakes using MODIS products in Northeast China. Int J Remote Sens 40:5388-5410. https://doi.org/10.1080/ 01431161.2019 .1579939

Yoo JC, D'Odorico P (2002) Trends and fluctuations in the dates of ice break-up of lakes and rivers in northern Europe: the effect of the North Atlantic Oscillation. J Hydrol 268:100-112

Publisher's note Springer Nature remains neutral with regard to jurisdictional claims in published maps and institutional affiliations. 